\title{
Prevalence of Virulence Genes and Antifungal Resistance in Candida albicans Isolated from Raw Goat Milk
}

\author{
Mona MH Soliman ${ }^{1 *}$, Mai M Kandil ${ }^{1}$, Elnemr $\mathrm{SA}^{2}$ and Azza SM Abuelnaga ${ }^{1}$ \\ ${ }^{l}$ Department of Microbiology and Immunology, National Research Centre, Doki, Egypt \\ ${ }^{2}$ Depatrtment of Chemistry, Animal Health Research Institute, Giza, Egypt \\ *Corresponding author’s Email: mona nrc.micro@yahoo.com; (D)orcid: 0000-0003-0871-0632
}

\begin{abstract}
The contamination of goat milk with pathogenic fungi can cause health hazards for the consumers either they consume it raw or even in the processed form. Since there are few studies concerning yeasts in raw goat milk, the present study aimed to determine the prevalence of yeasts and isolate Candida albicans from raw goat milk samples. Also, this study determined the distribution of virulence genes and the antifungal susceptibility profile of Candida albicans isolates. A total of 30 goat milk samples (collected from free-grazing goats) were mycologically examined. The confirmed Candida albicans isolates were subjected to PCR assay to detect the virulence genes (SAP4, RAS1, ALS1, HWP1, and PLB1). Also, antifungal sensitivity testing was performed against the commercially available antifungal agents and probiotics (Lactobacillus acidophilus and Lactobacillus plantarum). The mycological examination revealed that 14 out of $30(46.7 \%)$ goat milk samples were positive for yeasts and only $4(13.3 \%)$ isolates were confirmed as Candida albicans. The results from the PCR assay showed that RAS1 and ALS1 were found in $4(100 \%)$ isolates, HWP1 and SAP4 were found in $2(50 \%)$ isolates, while PLB1 was not detected in tested Candida albicans isolates (0\%). Antifungal sensitivity testing results showed that ketoconazole gave the best activity against Candida albicans isolates, followed by fluconazole, nystatin, and itraconazole. All isolates were resistant to terbinafine. Moreover, both Lactobacillus acidophilus and Lactobacillus plantarum showed antifungal effects against Candida albicans, but Lactobacillus plantarum was more effective than Lactobacillus acidophilus. Antifungal resistance is a major problem that can lead to failure of candidiasis treatment. Regular antifungal sensitivity testing and searching for an alternative bio-eco-friendly approach for proper control and treatment of candidiasis are strongly needed to prevent treatment failure and emergence of resistant isolates.
\end{abstract}

Keywords: Antifungal sensitivity testing, Candida albicans, Goat milk, Virulence genes, Probiotics.

\section{INTRODUCTION}

Yeasts are considered an important component of the microflora of dairy products and are usually found in large counts in milk because it is rich in proteins, sugars, lipids, and organic acids. Yeasts can cause biochemical deterioration in milk, leading to a serious impact on public health (Spanamberg et al., 2009). Fungi also affect milk quality and shelf life (Hasan and Yassein, 2018).

Genus Candida contains approximately 200 yeasts, of which Candida albicans is the most commonly isolated one. Candida species are opportunistic pathogens that are commensally found in the oral cavity, digestive system, and vagina. However, they can also cause systemic infections especially in immunocompromised and hospitalized persons (Hizlisoy et al., 2020). In Candida albicans pathogenesis, the adhesion and biofilm formation are assumed to be under the control of the hyphal wall protein1 (Hwp1) that is found on the surface of yeast hyphae (Sundstrom et al., 2002). Hwp1 encoding gene is part of a core of eight genes that are induced during the filamentation process of Candida albicans. The adhesion process of Candida albicans is also induced by agglutinin-like sequence 1 (ALS1) that facilitates the adherence to the endothelial cells of host and also it is important for hyphal development in addition to adherence to endothelial cells of the host (Fu et al., 2002). ALS1 and ALS3 are two genes with similar sequences and functions. Furthermore, phospholipase B (PLB1) helps in the pathogenesis of Candida albicans as it can mediate the systemic gastrointestinal tract manifestations (Samaranayake et al., 2005). The secreted aspartyl proteinases (Saps) help in the hydrolysis of peptide bonds of the host proteins, supposed to be a part of the virulence mechanism of Candida albicans (Naglik et al., 2003).

The existence of virulence genes and the elevation in the prevalence of resistance against antifungal agents have been incriminated in the pathogenesis of Candida albicans. The antifungal resistance is increasing due to the use of inadequate doses of the selective therapies as well as the frequent use of antifungal agents for fungal infection prophylaxis in both humans and animals (Mendes et al., 2018). However, the relationship between virulence genes and the resistance profiles of Candida albicans has not been sufficiently investigated, particularly in deep Candida albicans infections (Shrief et al., 2019). In recent years, alternative approaches to proper control and treatment of fungal diseases have been explored. 
Probiotic bacteria are utilized in animal and human feeding to stimulate the balance of intestinal microbiota of the body. They also improve digestion, strengthen the immune system, and promote the production of vitamins. The use of probiotics can reduce the use of antibiotics and enhance animal growth (De Baets et al., 2009). Lactobacillus acidophilus and Lactobacillus plantarum are considered the commonly isolated species of Lactobacillus in the gastrointestinal tract and are known as probiotics (Gudadappanavar et al., 2017). Lactobacillus species have the potential to produce different antimicrobial compounds such as acetic acid, hydrogen peroxide, lactic acid, and different types of bacteriocins such as small heat-tolerant lantibiotics (SHSL), non-lanthionine-incorporating membrane-active peptides (MAP), larger heat-sensitive proteins (LHLP), and complex bacteriocins that include one or various chemical constituents. Due to their capability to produce variable antimicrobial compounds, these probiotics can be used for treatment and control of various manifestations (Spinler et al., 2008).

The present work aimed to isolate Candida albicans from raw goat milk, detect virulence genes and perform the antifungal sensitivity testing against the commercially available antifungal agents (fluconazole, itraconazole, ketoconazole, terbinafine, and nystatin) as well as investigate the ability of probiotics (Lactobacillus acidophilus and Lactobacillus plantarum) to suppress the growth of Candida albicans.

\section{MATERIALS AND METHODS}

\section{Candida isolation and identification}

A total of 30 goat milk samples were collected from free-grazing goats, subcultured on Sabouraud dextrose agar plates, and incubated at $30{ }^{\circ} \mathrm{C}$ for $72 \mathrm{~h}$. Pure colonies were picked to make morphological, differential biochemical identification tests and germ tube test according to (Deorukhkar and Roushani, 2018).

\section{Virulence genes detection}

\section{DNA extraction}

DNA extraction was done using the QIAamp DNA Mini kit (Qiagen, Germany, GmbH) with modifications from the manufacturer's instructions. In brief, $200 \mu \mathrm{l}$ of the sample suspension was incubated with $10 \mu \mathrm{l}$ of proteinase $\mathrm{K}$ and 200 $\mu \mathrm{l}$ of lysis buffer at $56{ }^{\circ} \mathrm{C}$ for $10 \mathrm{~min}$. After the end of the incubation period, $200 \mu 1$ of $100 \%$ ethanol was added to this mixture. Washing and centrifugation of the sample were done according to the manufacturer's recommendations. The elution of fungal nucleic acid was done with $100 \mu$ l elution buffer provided with the extraction kit.

\section{Oligonucleotide primers}

Primers (Table 1) were supplied from Metabion (Germany).

Table 1. Sequences of primers, target genes, product sizes, and conditions of PCR cycles

\begin{tabular}{|c|c|c|c|c|c|c|c|c|}
\hline \multirow{2}{*}{$\begin{array}{l}\text { Target } \\
\text { genes }\end{array}$} & \multirow{2}{*}{$\begin{array}{l}\text { Primers sequences } \\
\left(5^{\prime}-3^{\prime}\right)\end{array}$} & \multirow{2}{*}{$\begin{array}{l}\text { Amplicon } \\
\text { size } \\
\text { (base pair) }\end{array}$} & \multirow{2}{*}{$\begin{array}{c}\text { Primary } \\
\text { denaturation }\end{array}$} & \multicolumn{3}{|c|}{ Amplification cycles (35 cycles) } & \multirow{2}{*}{$\begin{array}{c}\text { Final } \\
\text { extension }\end{array}$} & \multirow[b]{2}{*}{ References } \\
\hline & & & & $\begin{array}{c}\text { Secondary } \\
\text { denaturation }\end{array}$ & Annealing & Extension & & \\
\hline \multirow{2}{*}{ RASI } & $\begin{array}{l}\text { (Forward) } \\
\text { CCCAACTATTGAGGATTCTTATCGTAAA }\end{array}$ & \multirow{2}{*}{106} & \multirow{2}{*}{$\begin{array}{c}94^{\circ} \mathrm{C} \\
5 \mathrm{~min}\end{array}$} & \multirow{2}{*}{$\begin{array}{l}94^{\circ} \mathrm{C} \\
30 \mathrm{sec}\end{array}$} & \multirow{2}{*}{$\begin{array}{l}60^{\circ} \mathrm{C} \\
45 \mathrm{sec}\end{array}$} & \multirow{2}{*}{$\begin{array}{l}72^{\circ} \mathrm{C} \\
45 \mathrm{sec}\end{array}$} & \multirow{2}{*}{$\begin{array}{l}72^{\circ} \mathrm{C} \\
10 \mathrm{~min}\end{array}$} & \multirow[t]{2}{*}{$\begin{array}{l}\text { Tsang et al. } \\
\text { (2012) }\end{array}$} \\
\hline & (Reverse)TCTCATGGCCAGATATTCTTCTTG & & & & & & & \\
\hline \multirow{2}{*}{ ALS1 } & $\begin{array}{l}\text { (Forward) GAC TAG TGA ACC AAC AAA TAC } \\
\text { CAG A }\end{array}$ & \multirow[t]{2}{*}{318} & \multirow{2}{*}{$\begin{array}{c}94^{\circ} \mathrm{C} \\
5 \mathrm{~min}\end{array}$} & \multirow{2}{*}{$\begin{array}{l}94^{\circ} \mathrm{C} \\
30 \mathrm{sec}\end{array}$} & \multirow{2}{*}{$\begin{array}{c}50^{\circ} \mathrm{C} \\
40 \mathrm{sec}\end{array}$} & \multirow{2}{*}{$\begin{array}{l}72^{\circ} \mathrm{C} \\
40 \mathrm{sec}\end{array}$} & \multirow{2}{*}{$\begin{array}{l}72^{\circ} \mathrm{C} \\
7 \mathrm{~min}\end{array}$} & \multirow{4}{*}{$\begin{array}{l}\text { Inci et al. } \\
(2013)\end{array}$} \\
\hline & (Reverse) CCA GAA GAA ACA GCA GGT GA & & & & & & & \\
\hline \multirow{2}{*}{ HWP1 } & (Forward) ATG ACT CCA GCT GGT TC & \multirow{2}{*}{572} & \multirow{2}{*}{$\begin{array}{r}94^{\circ} \mathrm{C} \\
5 \mathrm{~min}\end{array}$} & \multirow{2}{*}{$\begin{array}{l}94^{\circ} \mathrm{C} \\
30 \mathrm{sec}\end{array}$} & \multirow{2}{*}{$\begin{array}{l}45^{\circ} \mathrm{C} \\
45 \mathrm{sec} .\end{array}$} & \multirow{2}{*}{$\begin{array}{l}72^{\circ} \mathrm{C} \\
45 \mathrm{sec} .\end{array}$} & \multirow{2}{*}{$\begin{array}{l}72^{\circ} \mathrm{C} \\
10 \mathrm{~min}\end{array}$} & \\
\hline & (Reverse) TAG ATC AAG AAT GCA GC & & & & & & & \\
\hline \multirow{2}{*}{$P L B 1$} & (Forward) ATGATTTTGCATCATTTG & \multirow{2}{*}{751} & \multirow{2}{*}{$\begin{array}{c}94^{\circ} \mathrm{C} \\
5 \mathrm{~min}\end{array}$} & \multirow{2}{*}{$\begin{array}{c}94^{\circ} \mathrm{C} \\
30 \mathrm{sec}\end{array}$} & \multirow{2}{*}{$\begin{array}{c}50^{\circ} \mathrm{C} \\
1 \mathrm{~min}\end{array}$} & \multirow{2}{*}{$\begin{array}{l}72^{\circ} \mathrm{C} \\
1 \mathrm{~min}\end{array}$} & \multirow{2}{*}{$\begin{array}{l}72^{\circ} \mathrm{C} \\
10 \mathrm{~min}\end{array}$} & \multirow{2}{*}{$\begin{array}{l}\text { Mukherjee } \\
\text { et al. } \\
\text { (2001) }\end{array}$} \\
\hline & (Reverse) AGTATCTGGAGCTCTACC & & & & & & & \\
\hline \multirow{2}{*}{ SAP4 } & (Forward) GCT CTT GCT ATT GCT TTA TTA & 394 & $94^{\circ} \mathrm{C}$ & $94^{\circ} \mathrm{C}$ & $49^{\circ} \mathrm{C}$ & $72^{\circ} \mathrm{C}$ & $72^{\circ} \mathrm{C}$ & Sikora et \\
\hline & (Reverse) TAG GAA CCG TTA TTC TTA CA & 4 & $5 \mathrm{~min}$. & $30 \mathrm{sec}$. & $45 \mathrm{sec}$. & $45 \mathrm{sec}$. & $10 \mathrm{~min}$. & al. (2011) \\
\hline
\end{tabular}

\section{PCR amplification}

The PCR reaction was performed in a $25-\mu 1$ reaction mixture containing $12.5 \mu 1$ of master mix (EmeraldAmp Max, Takara, Japan), $1 \mu$ l of each primer (20 pmol concentration), $4.5 \mu 1$ of distilled water, and finally $6 \mu$ l of template DNA. The reaction was done in the thermal cycler (Applied biosystem 2720, Germany).

\section{Analysis of PCR products}

Electrophoresis of the PCR products was performed on 1.5\% agarose gel (Applichem, Germany, GmbH) in 1x TBE buffer at ambient temperature using gradients of $5 \mathrm{~V} / \mathrm{cm}$. For gel electrophoresis, $15 \mu \mathrm{l}$ of the products was loaded in each gel slot. Gelpilot 100 bp DNA Ladder (Qiagen, Germany, GmbH) was used to determine the product size. Photographing the agarose gel was performed using a gel documentation system (Alpha Innotech, Biometra, Germany) and the data was analyzed through computer software. 


\section{Antifungal susceptibility testing}

\section{Cultures preparation}

The suspension of each Candida albicans isolate was prepared in sterile distilled water and was adjusted to 0.5 McFarland turbidity standard to obtain a concentration of $10^{6} \mathrm{CFU} / \mathrm{ml}$. Lactobacillus acidophilus DSMZ 20079 and Lactobacillus plantarum DSM 20179 were purchased from MIRCEN (Microbiological Resource Center), Faculty of Agriculture, Ain Shams University, Cairo, Egypt. Both strains were activated on de Man, Rogosa, and Sharp (MRS) broth (Biolife, Italy) at $37{ }^{\circ} \mathrm{C}$ for $24 \mathrm{~h}$. Serial dilutions were prepared to obtain a concentration of $10^{6} \mathrm{CFU} / \mathrm{ml}$.

\section{Well diffusion method}

The antifungal sensitivity testing was performed on Candida albicans isolates. The adjusted spore suspensions were evenly spread on the surface of Sabouraud dextrose agar plates. Holes were made on the medium by using a $6 \mathrm{~mm}$ cork borer. The commercial antifungal drugs, including fluconazole $(25 \mu \mathrm{g})$, itraconazole $(8 \mu \mathrm{g})$, ketoconazole (15 $\mu \mathrm{g})$, terbinafine $(1 \mu \mathrm{g})$, nystatin (100 IU). A volume of $100 \mu \mathrm{l}$ of the antifungal agent was placed into each well. Also, Lactobacillus acidophilus and Lactobacillus plantarum $\left(100 \mu \mathrm{l} /\right.$ well of $10^{6} \mathrm{CFU} / \mathrm{ml}$ suspension) were placed into the wells. The plates were then incubated at $37{ }^{\circ} \mathrm{C}$ for $24 \mathrm{~h}$. Zones of inhibition were measured in millimeters; the inhibition zone is the area surrounding the hole where there is no growth of inoculated fungus. All assays were carried out in triplicates to calculate the mean results (Abdullah et al., 2013).

\section{RESULTS AND DISCUSSION}

In the last decades, Candida species especially Candida albicans have been considered an important healthcareassociated infection (Cox, 1993). The discrimination of various Candida species mostly relies on different biochemical identifications, germ tube test, and the unique culture characteristics on specific media (Vijayalakshmi et al., 2016).

In the present study, 14 out of $30(46.7 \%)$ goat milk samples were positive for yeasts. Dos Santos and Marin (2005) isolated fungi from $32 \%$ of tested bovine milk specimens, of which $17.3 \%$ were Candida species. Dworecka-Kaszak et al. (2012) isolated fungi from only $14 \%$ of the tested samples also Krukowski et al. (2001) detected fungi in $9.6 \%$ of the tested milk specimens in the Lublin district located in Poland. Dos Santos and Marin (2005) declared that the percentage of fungal isolation in surveys performed in many countries varies significantly, with $6.1 \%$ rates as described in Egypt by Awad et al. (1980), 1.3\% in Denmark (Aalbek et al., 1994), and 12.07\% in Brazil (Costa et al., 1993).

Candida is mostly known as an opportunistic mycotic infection, and the origin of infection may come from the surface of the udder, milking machines, milker's palms, animal feed, straw, ground, sanitary agents, remedies, and other utensils. In immunosuppressive circumstances, the balance of pathogens population size may be altered, and the mycotic elements along with the other pathogens are capable of defeating the udder defensive techniques. Although the distribution of Candida species exhibits large diversity in different localities, it is crucial to give attention toward the increased cases of mammary gland infections caused by Candida species in the last decade (Dworecka-Kaszak et al., 2012). In the present work, only 4 (13.3\%) isolates were confirmed as Candida albicans. Spanamberg et al. (2014) isolated Candida albicans, Candida glabrata, Candida tropicalis, and Pichia guilliermondii from normal and mastitic ewe milk specimens. Candida albicans was the most frequently isolated species in a study performed by Costa et al. (1993) but Dworecka-Kaszak et al. (2012) isolated mostly Candida parapsilosis. Krukowski et al. (2001) stated that Candida kefyr, Candida cirferi, and Candida krusei were more frequently isolated from cow milk in Poland.

In the present work, the virulence genes were detected in the four isolates of Candida albicans (Table 2 and Figures 1-5). The results revealed that RAS1 and ALS1 were found in 4 (100\%) isolates, HWP1 and SAP4 were found in 2 $(50 \%)$ isolates but PLB1 was not detected in any of the four isolates $(0 \%)$. Similar results were obtained by Vijayalakshmi et al. (2016) who detected the virulence genes of HWP1 in 77\%, INT1 in 72\%, ALS1 in 65\%, SAP1 in $65 \%$, and PLB1 in 52\% of multi-drug resistant Candida albicans. Also, Abdul-Lateef et al. (2015) detected the virulence genes of INT1, ALS1 in a higher frequency (100\%), HWP1 in 90.9\%, SAP1 in 59.09\%, and PLB1 in $13.63 \%$ of tested Candida albicans isolates. However, Inci et al. (2013) detected the ALS1 gene in 53.9\% of tested Candida albicans isolates, while the HWP1 gene was found in only 5.3\% of tested isolates. The diversity in the prevalence percentages of virulence genes may attribute to various issues including the number of specimens under investigation and the difference in the isolation origins of Candida albicans (Vijayalakshmi et al., 2016).

Table 2. The distribution of the virulence genes in Candida albicans isolates recovered from goat milk

\begin{tabular}{llllll}
\hline Isolates & RAS1 & ALS1 & HWP1 & PLB1 & SAP4 \\
\hline $\mathbf{1}$ & + & + & - & - & - \\
\hline $\mathbf{2}$ & + & + & + & - & + \\
\hline $\mathbf{3}$ & + & + & + & - & + \\
\hline $\mathbf{4}$ & + & + & - & - & - \\
\hline
\end{tabular}




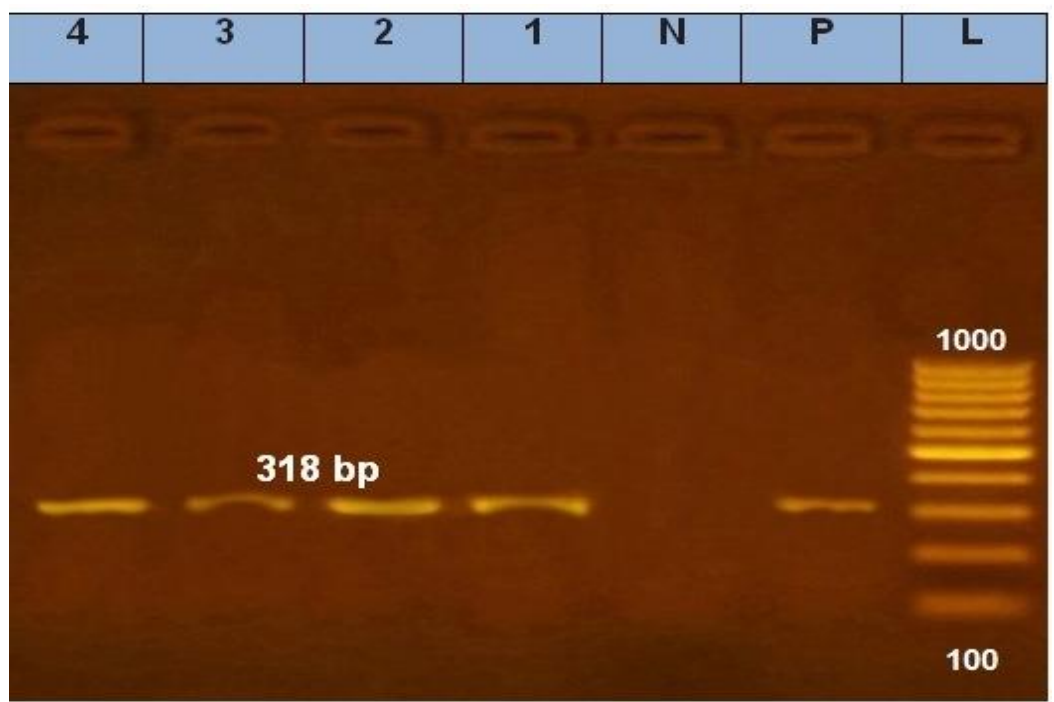

Figure 1. Agarose gel electrophoresis showing PCR-amplified product of ALS1 gene of Candida albicans derived from goat milk. (Lane L: 100-bp DNA ladder, Lane P: positive control, Lane N: negative control, Lanes 1-4: tested Candida albicans isolates).

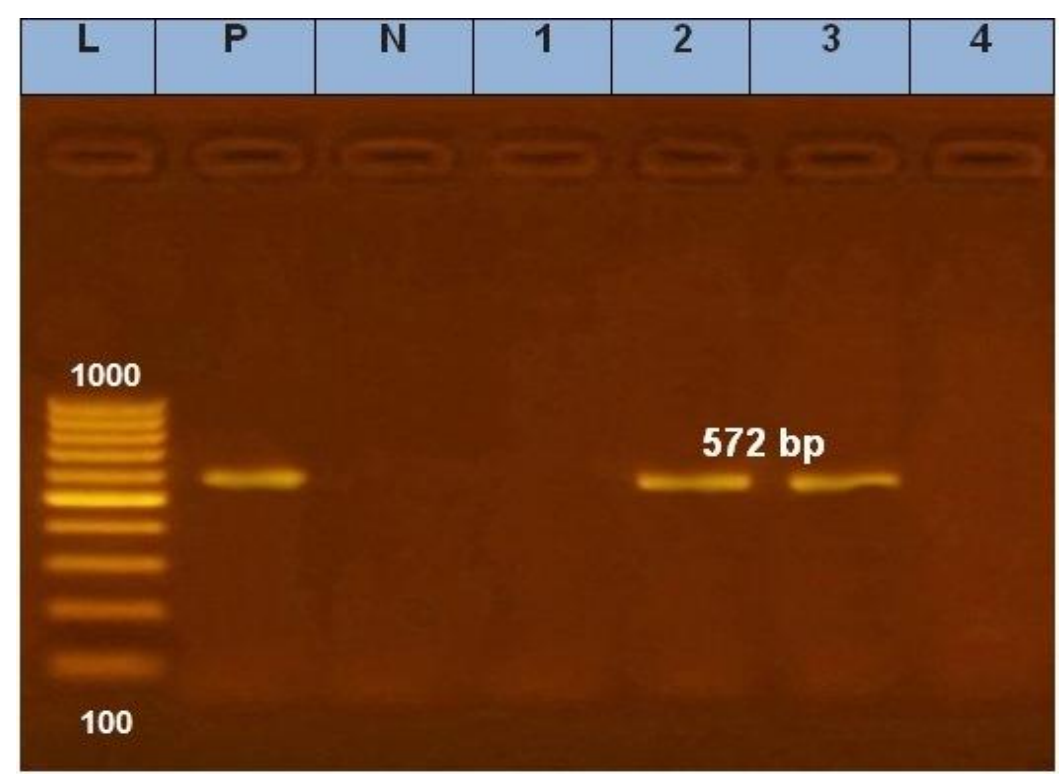

Figure 2. Agarose gel electrophoresis showing PCR-amplified product of HWP1 gene of Candida albicans derived from goat milk. (Lane L: 100-bp DNA ladder, Lane P: positive control, Lane N: negative control, Lanes 1-4: tested Candida albicans isolates).

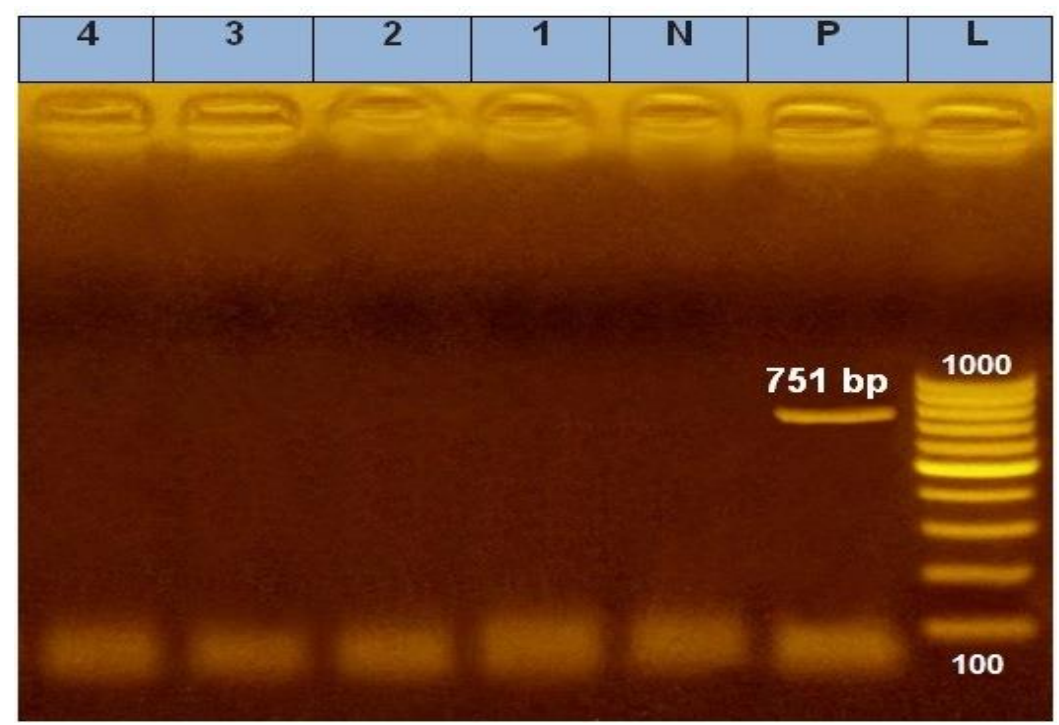

Figure 3 Agarose gel electrophoresis showing PCR-amplified product of PLB1 gene of Candida albicans derived from goat milk. (Lane L: 100-bp DNA ladder, Lane P: positive control, Lane N: negative control, Lanes 1-4: tested Candida albicans isolates). 


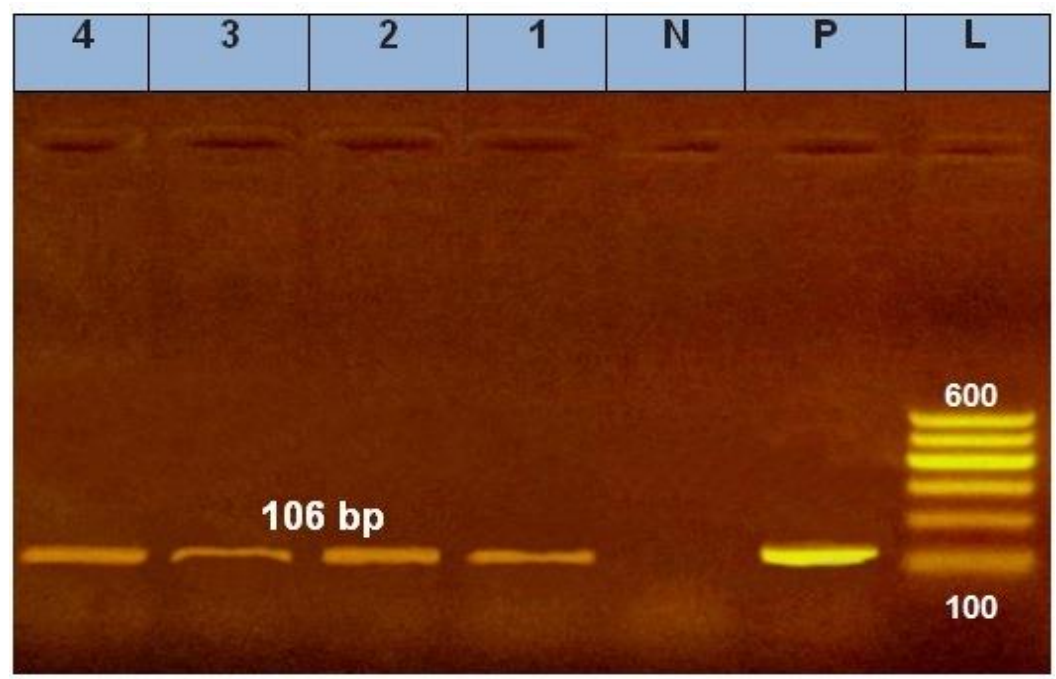

Figure 4. Agarose gel electrophoresis showing PCR-amplified product of RAS1 gene of Candida albicans derived from goat milk. (Lane L: 100-bp DNA ladder, Lane P: positive control, Lane N: negative control, Lanes 1-4: tested Candida albicans isolates).

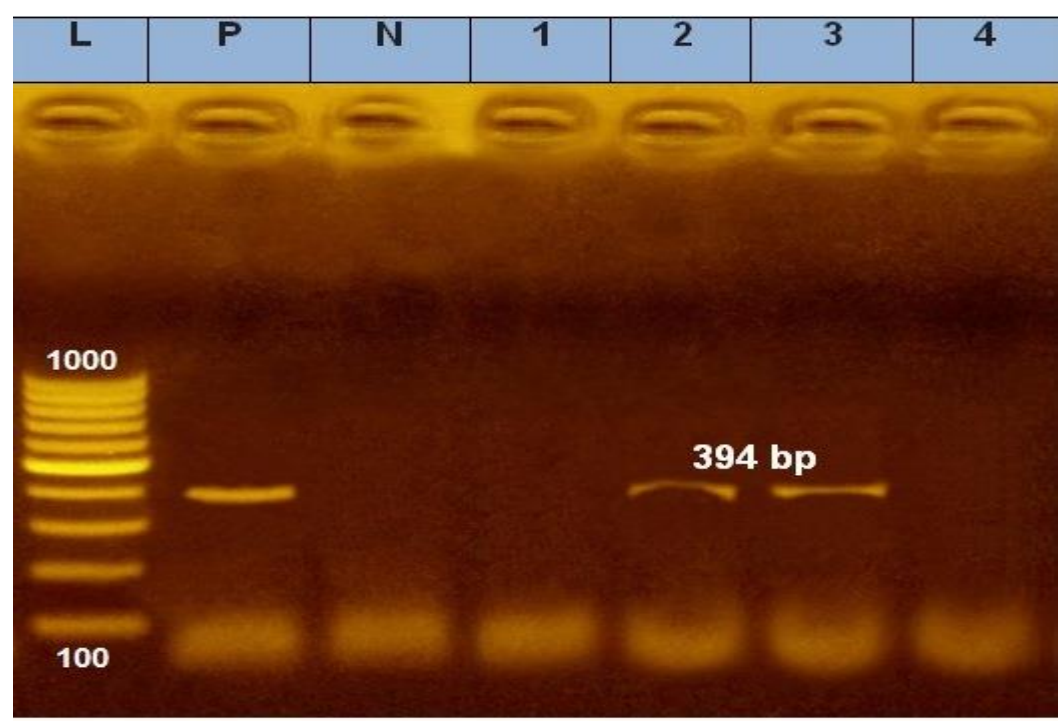

Figure 5. PCR results for the amplification of SAp4 gene of Candida albicans derived from goat milk. (Lane L: 100-bp DNA ladder, Lane P: positive control, Lane N: negative control, Lanes 1-4: tested Candida albicans isolates).

In recent years, antimycotic agents have shown an increase in usage as the fungal infections have also increased, leading to the suppression of endogenous fungal microflora, and the emergence of more resistant isolates due to the inhibition of susceptible ones (Koç, 2003). Some Candida species are naturally resistant to some antimycotics and it was revealed that many Candida isolates possess resistance against amphotericin B and others developed resistance against ketoconazole (Gunes et al., 2001). In the present study, ketoconazole showed the best activity against Candida albicans, followed by fluconazole. While nystatin and itraconazole showed lower activity against Candida albicans. All isolates were resistant to terbinafine (Table 3 and Figure 6).

Table 3. Results of antifungal sensitivity of Candida albicans isolates derived from goat milk against different antifungal agents and probiotics

\begin{tabular}{|c|c|c|c|c|c|c|c|}
\hline \multirow{2}{*}{$\begin{array}{l}\text { Candida } \\
\text { albicans } \\
\text { isolates }\end{array}$} & \multicolumn{7}{|c|}{ Inhibition zone diameter (mm) } \\
\hline & $\begin{array}{l}\text { Fluconazole } \\
\qquad(25 \mu \mathrm{g})\end{array}$ & $\begin{array}{l}\text { Itraconazole } \\
\quad(8 \mu \mathrm{g})\end{array}$ & $\begin{array}{l}\text { Ketoconazole } \\
\quad(15 \mu \mathrm{g})\end{array}$ & $\begin{array}{l}\text { Terbinafine } \\
\qquad(1 \mu \mathrm{g})\end{array}$ & $\begin{array}{l}\text { Nystatin } \\
\text { (100 IU) }\end{array}$ & $\begin{array}{c}\text { Lactobacillus } \\
\text { acidophilus }\left(1^{\wedge} 6\right)\end{array}$ & $\begin{array}{c}\text { Lactobacillus } \\
\text { plantarum } \\
\left(10^{\wedge} 6\right)\end{array}$ \\
\hline 1 & $22.7 \pm 1.5$ & $19.3 \pm 0.7$ & $33.3 \pm 0.9$ & Resistant & $22.3 \pm 0.3$ & 14. $7 \pm 0.3$ & $16.3 \pm 0.9$ \\
\hline 2 & $37.3 \pm 1.5$ & $21.7 \pm 0.9$ & $32.3 \pm 1.5$ & Resistant & $22 \pm 1$ & $12.3 \pm 0.3$ & $14.7 \pm 0.3$ \\
\hline 3 & $36.3 \pm 0.9$ & $21.3 \pm 0.9$ & $35.7 \pm 0.3$ & Resistant & $22.7 \pm 1.5$ & $13 \pm 0.6$ & $15 \pm 1.6$ \\
\hline 4 & $29 \pm 2.1$ & $18.3 \pm 0.9$ & $31.7 \pm 0.9$ & Resistant & $21 \pm 0.6$ & 11. $7 \pm 0.9$ & $13.3 \pm 0.9$ \\
\hline
\end{tabular}




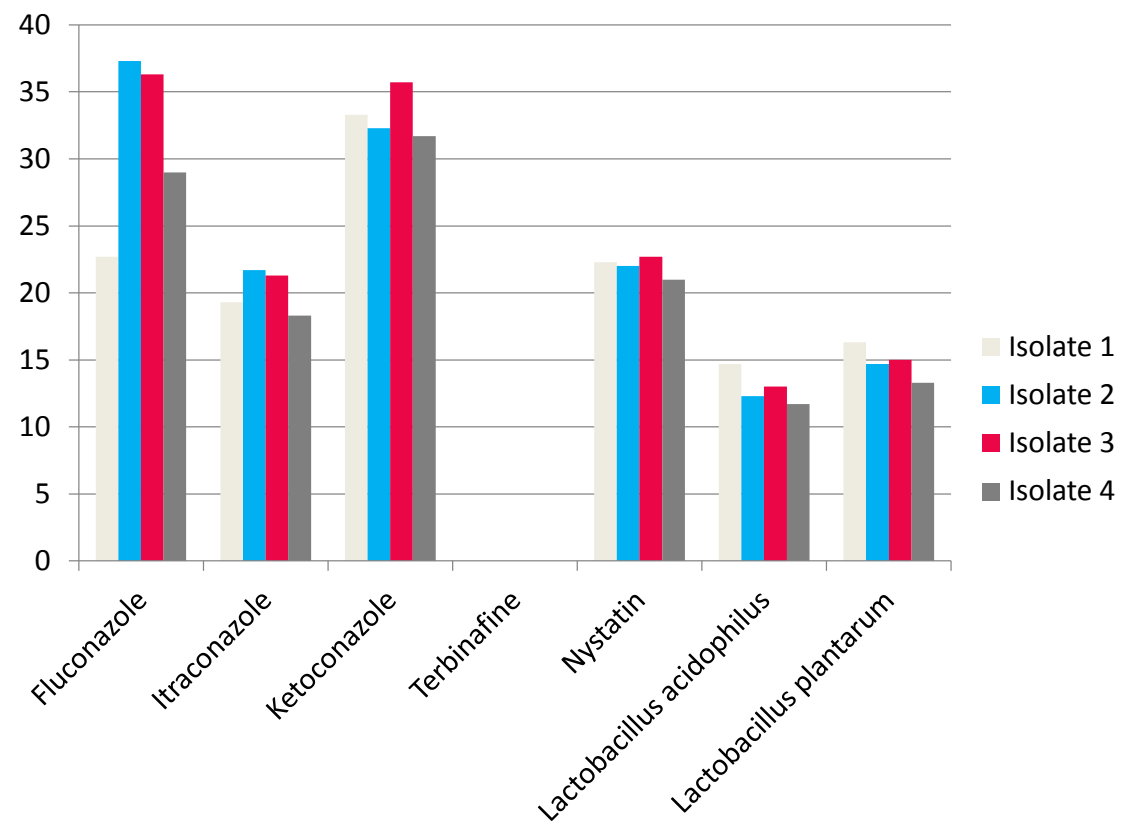

Figure 6. Comparison of the antifungal sensitivity results of Candida albicans isolates against commercially available antifungal agents and probiotics.

Sonmez and Erbas (2017) found high resistance rate (100\%) to fluconazole, miconazole, amphotericin B, and flucytosine while high susceptibility to ketoconazole. Two (20\%) Candida albicans isolates were found to be highly susceptible to nystatin while others were of medium susceptibility hence Sonmez and Erbas (2017) concluded that ketoconazole is the drug of choice in treating Candida infections. Lyon et al. (2010) found that the susceptibility of fluconazole significantly increased from $87.5 \%$ in 2005 to $97.4 \%$ in 2007. Furthermore, Monroy-Pérez et al. (2016) stated that all strains of Candida albicans were sensitive to nystatin, and $37(94.9 \%)$ and 38 (97.4\%) strains were resistant to fluconazole and ketoconazole, respectively. Shrief et al. (2019) declared that the resistance against antifungal drugs including itraconazole, fluconazole, and caspofungin was $8 \%$ for each one and $9 \%$ for amphotericin B. Moreover, Dos Santos Abrantes et al. (2014) reported that more than 50\% of Candida albicans isolates obtained from South Africa and Cameroon showed resistance against fluconazole. However, an earlier study conducted in South Africa revealed $100 \%$ susceptibility of Candida albicans to fluconazole because this study was performed before the introduction of fluconazole to HIV-AIDS patients as the fluconazole resistance was not developed yet (Blignaut et al., 2002). In the last years, the increase in clinical manifestations due to Candida species and the different sensitivity patterns against the used antifungal agents highlight the importance of in vitro susceptibility testing in selecting appropriate antifungal agents (Sonmez and Erbas, 2017). Antifungal susceptibility testing is a great tool that may specify clinical response, help in the efficient selection of antifungal agents, and predict antifungal treatment failure. Antifungal susceptibility testing of Candida species and tracing the emergence of resistant isolates is of great importance in order to make information available to the clinicians for a proper therapeutic outcome (Khan et al., 2018).

Due to the elevated prevalence of candidiasis in immunodeficient individuals, the emergence of resistance in Candida species to current antimycotics, the treatment failures and the frequent relapse of candidiasis, the use of some beneficial and harmless compounds such as probiotics for the treatment and control of this disease can be recommended as an interesting safe medicinal way (Silva et al., 2016). Probiotics can be used to effectively combat pathogens with no adverse effect on normal microbiota. In this concern, the use of probiotics can be a substitute in the food and pharmaceutical industries (Abdhul et al., 2015). In the current study, both Lactobacillus plantarum and Lactobacillus acidophilus showed antifungal activity against Candida albicans but Lactobacillus plantarum showed higher activity in comparison to Lactobacillus acidophilus. These results were similar to those obtained by Hasslöf et al. (2010) who revealed that Lactobacillus acidophilus had weaker inhibition activity in comparison with the other probiotic strains. Also, Strus et al. (2005) assured that tested probiotics, including Lactobacillus plantarum and Lactobacillus acidophilus, suppressed the growth of Candida albicans to a certain degree. Kovachev and Vatcheva-Dobrevska (2015) revealed that local application of probiotics such as Lactobacillus acidophilus may improve the effectiveness of conventional antimycotics and prevent recurrent infection in women with Candida albicans vaginal manifestation. Jiang et al. (2014) revealed that Candida albicans was the most susceptible yeast to lactobacilli but another study conducted by Salari and Almani (2020) found that cell concentrations of $10^{2}$ to $10^{10} \mathrm{CFU} / \mathrm{ml}$ for both Lactobacillus acidophilus and Lactobacillus plantarum were able to suppress the growth of most of the tested Candida species, except for Candida albicans, however, Candida albicans displayed very high susceptibility to cell-free supernatants of two Lactobacillus species. The differences in the results of various studies may attribute to differences in the clinical isolates of Candida 
albicans, the examined Lactobacillus strains, the investigations used for testing the antifungal susceptibility, tested Candida species, the initial counts of Lactobacillus species, the length of the incubation period, and the source of the Candida species isolation.

\section{CONCLUSION}

In the current study, both probiotics Lactobacillus acidophilus and Lactobacillus plantarum exhibited antifungal effects against Candida albicans. However, Lactobacillus plantarum was higher in the activity than Lactobacillus acidophilus. Fungal mastitis cases due to Candida species are spreading and candidiasis cases in immunocompromised individuals are also increasing along with the development of resistant strains that can lead to treatment failures. Plus the synthetic antimycotics have serious side effects. Therefore, further studies on experimentally infected animals are strongly recommended to evaluate the antifungal activity of Lactobacillus acidophilus, Lactobacillus plantarum, and other Lactobacillus species and determine their precise mode of action.

\section{DECLARATIONS}

\section{Authors' contribution}

Mona MH Soliman designed the plan of the study, shared in performing the experiments and writing of the manuscript. Mai M Kandil shared in performing the experiments and manuscript writing. Elnemr SA shared in performing the experiments and shared in analyzing the data. Azza SM Abuelnaga shared in performing the experiments and analyzing the data. All authors read and approved the final manuscript.

\section{Competing interests}

The authors declare that they have no competing interests.

\section{REFERENCES}

Aalbek B, Stenderup J, Jensen HE, Valbak J, Nylin B, and Huda A (1994). Mycotic and algal bovine mastitis in Denmark. Acta Pathologica, Microbiologica et Immunologica, 102(6): 451-456. DOI: https://doi.org/10.1111/j.1699-0463.1994.tb04898.x

Abdhul K, Ganesh M, Shanmughapriya S, Vanithamani S, Kanagavel M, Anbarasu K, and Natarajaseenivasan K (2015). Bacteriocinogenic potential of a probiotic strain Bacillus coagulans [BDU3] from Ngari. International Journal of Biological Macromolecules, 79: 800-806. DOI: https://doi.org/10.1016/j.ijbiomac.2015.06.005

Abdullah K, Soliman M, and Mohamed M (2013). Susceptibility of Candida albicans clinical isolates to some plant extracts in Saudi Arabia. Zagazig University Medical Journal, 19(5): 1-6. DOI: https://doi.org/10.21608/zumj.2013.4279

Abdul-Lateef LAR, AL- Kafhaji KA, and Al-Saddam ASK (2015). Genetic identification of some virulence factors of Candida albicans in candidal intertrigo of diabetic patients in Hilla Province/ Iraq. Australian Journal of Basic and Applied Sciences, 9: 66-72.

Awad FI, El Molla A, Fayed A, Abd el-Halim M, and Refai M (1980). Studies of mycotic mastitis in Egypt. Journal of Egyptian Veterinary Medical Association, 40(3): 35-41. Available at: https://www.worldcat.org/title/journal-of-the-egyptian-veterinary-medical-association/oclc/3610675

Blignaut E, Messer S, Hollis RJ, and Pfaller MA (2002). Antifungal susceptibility of South African oral yeast isolates from HIV/AIDS patients and healthy individuals. Diagnostic Microbiology and Infectious Disease, 44(2): 169-174. DOI: https://doi.org/10.1016/s0732-8893(02)00440-6

Costa EO, Gandra CR, Pires MF, Coutinho SD, Castilho W, and Teixeira CM (1993). Survey of bovine mycotic mastitis in dairy herds in the State of São Paulo, Brazil. Mycopathologia, 124(1): 13-17. DOI: https://doi.org/10.1007/bf01103051

Cox G (1993). Fungal infections. Current Opinion in Infectious Disease, 6: 422-426. Available at: https://journals.lww.com/coinfectiousdiseases/pages/default.aspx

De Baets L, Van Iwaarden P, Meeus N, Schimmel H, Philipp W, and Emons H (2009). First certified reference materials for molecular fingerprinting of two approved probiotic Bacillus strains. International Journal of Food Microbiology, 129(1): 16-20. DOI: https://doi.org/10.1016/j.ijfoodmicro.2008.10.028

Deorukhkar SC, and Roushani S (2018). Identification of Candida species: conventional methods in the era of molecular diagnosis. Annals of Microbiology and Immunology, 1(1): 1002-1008. Available at: http://www.remedypublications.com/annals-of-microbiology-and-immunologyhome.php

Dos Santos Abrantes PM, McArthur CP, and Africa CW (2014). Multi-drug resistant oral Candida species isolated from HIV-positive patients in South Africa and Cameroon. Diagnostic Microbiology and Infectious Disease, 79(2): 222-227. DOI: http://dx.doi.org/10.1016/j.diagmicrobio.2013.09.016

Dos Santos RDC, and Marin JM (2005). Isolation of Candida spp. from mastitic bovine milk in Brazil, Mycopathologia, 159(2): 251-253. DOI: https://DOI.org/10.1007/s11046-004-2229-2

Dworecka-Kaszak B, Krutkiewicz A, Szopa D, Kleczkowski M, and Biegańska M (2012). High prevalence of Candida yeast in milk samples from cows suffering from mastitis in Poland. The Scientific World Journal, Article ID 196347. DOI: https://doi.org/10.1100/2012/196347

Fu Y, Ibrahim AS, Sheppard DC, Chen Y, French SW, Cutler JE, Filler SG, and Edwards JE (2002). Candida albicans Als1p: An adhesin that is a downstream effector of the EFG1 filamentation pathway. Molecular Microbiology, 44(1): 61-72. DOI: https://doi.org/10.1046/j.13652958.2002.02873.x

Gudadappanavar AM, Hombal PR, Timashetti SS, and Javali SB (2017). Influence of Lactobacillus acidophilus and Lactobacillus plantarum on wound healing in male Wistar rats- an experimental study. International Journal of Applied and Basic Medical Research, 7: 233-238. DOI: https://doi.org/10.4103/ijabmr.ijabmr_329_16 
Gunes I, Kalkanci A, and Kustimur S (2001). Comparison of three different commercial kits with conventional methods for the identification of Candida strains to species level. Mikrobiyoloji Bulteni, 35: 559-564. Available at: http://www.mikrobiyolbul.org/managete/fu_folder/200104/2001-35-04-559-564.pdf

Hasan KAM, and Yassein SN (2018). Prevalence and type of fungi in milk from goats with subclinical mastitis. Online Journal of Veterinary Research, 22(8): 669-674.

Hasslöf P, Hedberg M, Twetman S, and Stecksen-Blicks C (2010). Growth inhibition of oral mutans streptococci and Candida by commercial probiotic lactobacilli — an in vitro study. BMC Oral Health, 10: 18. DOI: https://doi.org/10.1186/1472-6831-10-18

Hizlisoy H, Onmaz NE, Al S, Karadal F, Yildirim Y, Gonulalan Z, Semih Gumussoy K, Aydemir GD, Tekinsen FK and Dinc G (2020). Clonal diversity and antifungal susceptibility of Candida spp. recovered from cow milk. Mljekarstvo/Dairy, 70(1): 40-49. DOI: https://doi.org/10.15567/mljekarstvo.2020.0104

İnci M , Atalay MA, Özer B, Evirgen Ö, Duran N, Motor VK, Koç AN, Önlen Y, Kilinç C, and Durmaz S (2013). Investigations of ALS1 and HWP1 genes in clinical isolates of Candida albicans. Turkish Journal of Medical Sciences, 43: 125-130. Available at: https://journals.tubitak.gov.tr/medical/index.htm

Jiang Q, Stamatova I, Kari K, and Meurman JH (2014). Inhibitory activity in vitro of probiotic lactobacilli against oral Candida under different fermentation conditions. Beneficial Microbes, 6: 361-368. DOI: https://doi.org/10.3920/bm2014.0054

Khan M, Ahmed J, Gul A, Ikram A, and Lalani FK (2018). Antifungal susceptibility testing of vulvovaginal Candida species among women attending antenatal clinic in tertiary care hospitals of Peshawar. Infection and Drug Resistance, 11: 447. DOI:_ https://doi.org/10.2147/idr.s153116

Koç N (2003). Antifungal resistance in our country. 3. National Fungal Diseases and Clinical Mycology Congress (27-30 May 2003) Congress Book. Bornova, Izmir, Turkey, pp. 285-300. Available at: http://ecmm.eu/ECMM N06_1-2003_A3.pdf

Kovachev SM, and Vatcheva-Dobrevska RS (2015). Local probiotic therapy for vaginal Candida albicans infections. Probiotics and Antimicrobial Proteins, 7: 38-44. Available at: https://doi.org/10.1007/s12602-014-9176-0

Krukowski H, Tietze M, Majewski T, and Rózański P (2001). Survey of yeast mastitis in dairy herds of small-type farms in the Lublin region, Poland. Mycopathologia, 150(1): 5-7. DOI: https://doi.org/10.1023/a:1011047829414

Lyon GM, Karatela S, Sunay S, and Adiri Y (2010). Antifungal susceptibility testing of Candida isolates from the Candida surveillance study. Journal of Clinical Microbiology, 48(4): 1270-1275. DOI: https://doi.org/10.1128/jcm.02363-09

Mendes JF, Gonçalves CL, Ferreira GFD, Esteves IA, Freitas CHD, Villarreal JPV, Mello JRBD, Meireles MCA, and Nascente PDS (2018). Antifungal susceptibility profile of different yeasts isolates from wild animals, cow's milk with subclinical mastitis and hospital environment. Brazilian Journal of Biology, 78(1): 68-75. DOI: https://doi.org/10.1590/1519-6984.04916

Monroy-Pérez E, Paniagua-Contreras GL, Rodríguez-Purata P, Vaca-Paniagua F, Vázquez-Villaseñor M, Díaz-Velásquez C, Uribe-García A, and Vaca S (2016). High virulence and antifungal resistance in clinical strains of Candida albicans. Canadian Journal of Infectious Diseases and Medical Microbiology, pp. 1-7. DOI: https://doi.org/10.1155/2016/5930489

Mukherjee PK, Seshan KR, Leidich SD, Chandra J, Cole GT, and Ghannoum MA (2001). Reintroduction of the PLB1 gene into Candida albicans restores virulence in vivo. Microbiology, 147: 2585-2597. DOI: https://doi.org/10.1099/00221287-147-9-2585

Naglik JR, Challacombe SJ, and Hube B (2003). Candida albicans secreted aspartyl proteinases in virulence and pathogenesis. Microbiology and Molecular Biology Reviews, 67(3): 400-428. DOI: https://doi.org/10.1128/mmbr.67.3.400-428.2003

Salari S, and Almani PGN (2020). Antifungal effects of Lactobacillus acidophilus and Lactobacillus plantarum against different oral Candida species isolated from HIV/AIDS patients: an in vitro study. Journal of Oral Microbiology, 12(1): 1769386. DOI: https://doi.org/10.1080/20002297.2020.1769386

Samaranayake YH, Dassanayake RS, Jayatilake JAMS, Cheung BPK, Yau JYY, Yeung KWS, and Samaranayake LP (2005). Phospholipase B enzyme expression is not associated with other virulence attributes in Candida albicans isolates from patients with human immunodeficiency virus infection. Journal of Medical Microbiology, 54(6): 583-593. DOI: https://doi.org/10.1099/jmm.0.45762-0

Shrief R, Zaki, MES, El-Sehsah EM, Ghaleb S, and Mofreh M (2019). Study of antifungal susceptibility, virulence genes and biofilm formation in Candida albicans. The Open Microbiology Journal, 13(1): 241-248. DOI: https://doi.org/10.2174/1874285801913010241

Sikora M, Dabkowska M, Swoboda-Kopec E, Jarzynka S, Netsvyetayeva I, Jaworska-Zaremba M, Pertkiewicz M, and Mlynarczyk G (2011). Differences in proteolytic activity and gene profiles of fungal strains isolated from the total parenteral nutrition patients. Folia Microbiologica, 56: 143-148. DOI: https://doi.org/10.1007/s12223-011-0023-3

Silva MP, Rossoni RD, Junqueira JC, and Jorge AOC (2016). Probiotics for Prevention and Treatment of Candidiasis and Other Infectious Diseases: Lactobacillus spp. and Other Potential Bacterial Species. In: Rao V, Rao L, eds. Probiotics and Prebiotics in Human Nutrition and Health. IntechOpen, London, UK, pp. 242-262. DOI: https://doi.org/10.5772/64093

Sonmez M, and Erbas G (2017). Isolation and identification of Candida spp. from mastitis cattle milk and determination of antifungal susceptibilities. International Journal of Veterinary Science, 6(2): 104-107.

Spanamberg A, Fraga CF, Ferreiro L, Aguinsky MS, Sanches EMC, Roehe C, Lautert C, and Santurio JM (2014). Yeasts in the Raw Ewe's Milk. Acta Scientiae Veterinariae, 42: 1236. DOI: https://doi.org/10.22456/1679-9216.16897

Spanamberg A, Ramos JP, Leoncini O, Alves SH, and Valente P (2009). High frequency of potentially pathogenic yeast species in goat's raw milk and creamed cheese in Southern Brazil. Acta Scientiae Veterinariae, 37(2): 133-141. DOI: https://doi.org/10.22456/1679-9216.16239

Spinler JK, Taweechotipatr M, Rognerud CL, Ou CN, Tumwasorn S, and Versalovic J (2008). Human-derived probiotic Lactobacillus reuteri demonstrate antimicrobial activities targeting diverse enteric bacterial pathogens. Anaerobe, 14: 166-171. DOI: https://doi.org/10.1016/j.anaerobe.2008.02.001

Strus M, Kucharska A, Kukla G, Brzychczy-Wloch M, Maresz K, and Heczko PB (2005). The in vitro activity of vaginal Lactobacillus with probiotic properties against Candida. Infectious Diseases in Obstetrics and Gynecology, 13: 69-75. DOI: https://doi.org/10.1080/10647440400028136

Sundstrom P, Balish E, and Allen CM (2002). Essential role of the Candida albicans transglutaminase substrate, hyphal wall protein 1, in lethal oroesophageal candidiasis in immunodeficient mice. The Journal of Infectious Diseases, 185(4): 521-530. DOI: https://doi.org/10.1086/338836

Tsang PWK, Bandara HMHN, and Fong WP (2012). Purpurin suppresses Candida albicans biofilm formation and hyphal development. PLoS One, 7(11): e50866. DOI: https://doi.org/10.1371/journal.pone.0050866

Vijayalakshmi P, Thenmozhi S, and Rajeswari P (2016). The Evaluation of the virulence factors of clinical Candida isolates and the anti-biofilm activity of Elettaria cardamomum against multi-drug resistant Candida albicans. Current Medical Mycology, 2(2): 8-15. DOI: https://doi.org/10.18869/acadpub.cmm.2.2.3 